\title{
Invasive Alien Plants In Brazil: A Nonrestrictive Revision of Academic Works
}

\author{
Jézili Dias ${ }^{1}$, Maria Augusta Monteiro Assis da Fonte1, Robson Baptista1, \\ Maurício Cruz Mantoani ${ }^{1}$, Daniela Roberta Holdefer ${ }^{2} \&$ Jose Marcelo Domingues Torezan ${ }^{1 *}$
}

\author{
${ }^{1}$ Laboratório de Biodiversidade e Restauração de Ecossistemas, Departamento de Biologia Animal e Vegetal, \\ Centro de Ciências Biológicas, , Universidade Estadual de Londrina - UEL, Londrina, PR, Brasil \\ ${ }^{2}$ Faculdade Estadual de Filosofia, Ciências e Letras de União da Vitória - FAFIUV, União da Vitória, PR, Brasil
}

\begin{abstract}
Recent papers about invasive plants in Brazil have highlighted the scarcity of criteria for determining invasiveness status. Here, we reviewed papers published in academic journals before March 2012, together with undergraduate monographs, theses and dissertations and abstracts from meetings in ecology, botany and related fields, in order to list plants reported as invasive and verify the criteria used. A total of 124 works were listed, of which $45.9 \%$ reported quantitative samples and $35 \%$ dealt with Atlantic Forest, $18.5 \%$ with Cerrado and $17.8 \%$ with Caatinga, the most affected vegetation domains. Invasive behavior was supported by field data for only 54 alien species. Actual figures could be larger; however, the need for further research cannot be used as a justification for inaction in terms of public policy, and the precautionary principle should be employed in implementing temporary solutions in order to avoid irreversible damage.
\end{abstract}

Key words: Atlantic Forest, Cerrado, Caatinga, Invasive Potential.

\section{Introduction}

Exotic species are defined as those that originate from other biogeographic regions and are therefore neither native nor indigenous (Lockwood et al. 2007). Many exotic species that have been introduced accidentally or intentionally into ecosystems not only survive, but also adapt and occasionally begin to compete with native species, causing changes in the invaded ecosystem. Invasion by exotic species can change the characteristics and functioning of natural ecological processes, reducing native populations and leading to biodiversity loss (Mack et al. 2000; Lockwood et al. 2007). It is widely accepted that invasive species represent a global threat, in particular to protected (Martins et al. 2004) and restored areas (Lockwood et al. 2007).

It is difficult to determine general characteristics of invasive plants (Lockwood et al. 2007; Van Kleunen et al. 2010), but Schmidt \& Drake (2011) suggest that invasive species share common biological traits such as chromosome number and seed mass and that, overall, invasive plants are frequently reported to show fast growth, few pathogens, high resource-capture efficiency (Blumenthal 2006; Seastedt

\footnotetext{
*Send correspondence to: Jose Marcelo D. Torezan Laboratório de Biodiversidade e Restauração de Ecossistemas, Departamento de Biologia Animal e Vegetal, Centro de Ciências Biológicas, Universidade Estadual de Londrina UEL, CP 6001, CEP 86051-990, Londrina, PR, Brasil E-mail: torezan@uel.br
}

2009) and great phenotypic plasticity (Droste et al. 2010), allowing them great success in new environments, thus being able to displace native species.

However, not all exotic species are invasive, and an observed invasive behavior in a specific context cannot be used as a universal predictor of invasive potential in other environments (Randall et al. 2008). Indeed, most introduced species do not progress beyond the early stages of the invasion process and few species establish stable populations and even fewer become invasive (Mack et al. 2000). The success of the invasion process does not only depend on species attributes, but also on the nature, history and dynamics of the invaded ecosystems (Lockwood et al. 2007). Meiners et al. (2001) highlight that the sole arrival of an exotic plant, or its establishment per se, may not affect biodiversity, but its dominance in the environment can result in native species loss. Nonetheless, both native and non-native species can cause ecosystem change when they possess traits enabling them to exploit increasingly disturbed and eutrophic contemporary environments (Thompson \& Davis 2011), and even some exotics may show positive impacts on native species or ecosystems (Goodenough 2010).

Reports of invasive species in Brazil have been growing significantly, and the issue has been increasingly factored into public policy, in line with global trends of increased 
concern about biological invasions. Some states, such as the state of Paraná, have issued an official list of invasive species and have begun to regulate economic activities that make use of these species. However, any listing must be grounded in sound science (Sandvik et al. 2013), and research in ecology and conservation has much to contribute. Without precluding the adoption of precautionary practices, the control and eradication of invasive species in natural areas should be based on solid ecological knowledge, starting with a scientifically based determination of the invasive behavior.

A common tool used to address the issue of invasive species is to compile lists, primarily in collaborative databases, but also in regular scientific papers (Petenon \& Pivello 2008; Zenni \& Ziller 2011). However, the mechanisms for determining invasive behavior often fail to observe basic precepts (such as starting from an assessment of both site history and plant population data), relying on subjective information, and therefore probably inflating the lists (Randall et al. 2008). On the other hand, the existence of research gaps and the huge variation in how the risks posed by alien species are assessed can lead to delayed detection or even failure to detect new invasive species (Sandvik et al. 2013).

The goal of this paper was to review the scientific literature on invasive alien species in Brazil, determine the methods used to obtain information, and then compile a critical list of species presumed to be invasive, in order to discuss actual invasive status.

\section{Material and Methods}

We reviewed all papers published before March 2012 in scientific journals, undergraduate monographs, theses, dissertations and abstracts from meetings in ecology, botany and related fields. All studies that contained the expressions "invasive species" or "biological invasion" in their title or that referred to these expressions in the keywords were included. Beyond papers in journals with a peer review system, other types of academic publications (such as theses, dissertations, meeting annals and abstracts) were included because they were found to comprise a very large proportion of the available information and are used to supply databases and to support public policies, such as official listings. These works were excluded when the same research was unequivocally published in peer-reviewed journals.

Papers were organized according to the reported species, vegetation domain affected, country region, invasion site and assessment method. The following characteristics were verified in order to evaluate the assessment method: (i) sampling type (quantitative or qualitative), if applicable, (ii) use of replicates, and (iii) use of repeated sampling.

After compiling information, the criteria used by each author to assign invasive status to an exotic plant species were classified into the following categories, in increasing order of scientific rigor: 1. Invasive Potential (IP) inferred from invading behavior noticed only in another countries; 2. IP assigned by species ecophysiological characteristics, but with no field observations; 3. IP assigned based on observations of other researchers and from open-access collaborative databases; 4 . IP assigned through qualitative field studies; and 5. IP assigned through quantitative field studies. For categories 4 and 5, observations could have been carried out at a single location or at several locations (replicates), and at a single point in time or using repeated monitoring.

\section{Results}

A total of 124 published works reporting Invasive Exotic Species (IES) in Brazil were found (Table S1). Of these studies, $51.6 \%$ came from scientific journals (49\% in Brazilian journals), $34.7 \%$ from abstracts of scientific meetings and $13.7 \%$ from other academic works (undergraduate, masters and $\mathrm{PhD}$ degrees). About $35.5 \%$ of the papers dealt with the Atlantic Forest (Dense Rainforest 14\%, Mixed Rainforest 1\%, Seasonal Forest $17 \%$ and restoration sites 3\%), 18.5\% with Cerrado, $17.8 \%$ with Caatinga, $8.8 \%$ with Natural Grasslands and $12.9 \%$ did not explicitly identify their target vegetation domains or refer to human environments (Figure 1).

The criteria for assigning invasive behavior varied greatly among the studies. Some species, for which invasive behavior is improbable (e.g., species that disappear if not cultivated) and had their invasion prognostic based solely on reports from other countries, were excluded from the list, such as Brassica oleracea (Brassicaceae, common cabbage) and Chrysanthemum frutescens L. (Asteraceae, daisy) (Biondi \& Macedo 2008).

The final list contained 177 species from 57 families found in Brazilian territory (Table S2). When we examined the criteria used to identify invasion potential, only 54 IES had at least one report classified in categories 4 (qualitative field data) or 5 (quantitative field data), therefore probably presenting invasive behavior in Brazil.

Of the 123 species for which there was only weak evidence for invasive behavior, $4 \%$ were identified as having invasive potential because of their reported germination, seed dispersal or other ecophysiological characteristics, and $65 \%$ of the species were reported as IES based on informal reports from colleagues and other institutional sources. Of the 54 species reported as IES based on field work, 12\% were qualitative observations, in a single location (9.6\%) or in several locations (2.4\%), while of the studies based on field quantitative sampling, $31 \%$ were based on a single location and date and $11 \%$ involved repeated monitoring.

\section{Discussion}

The bias towards Atlantic Forest in the results probably reflects the age and intensity of human occupation in eastern Brazil, which can cause an increase in biological invasions, 
Publishing media
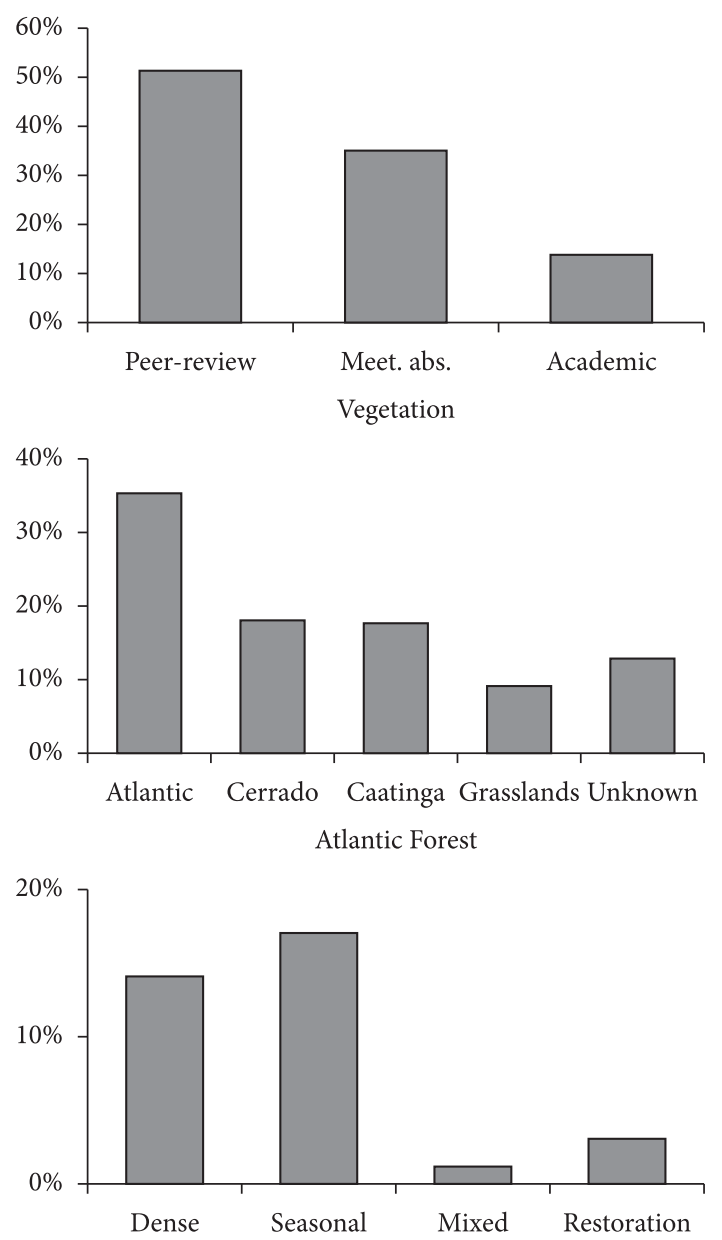

Figure 1. Proportional distribution of scientific works dealing with invasive exotic plant species in Brazil (until March 2012). At the top, distribution by publishing category (Peer-review: articles in peer-reviewed journals; Meet. Abs.: Scientific meeting abstracts; Academic: undergraduate monographs, dissertations, $\mathrm{PhD}$ theses). In the center, distribution of vegetation domains (Atlantic Forest; Cerrado; Caatinga; Subtropical Grasslands; Unknown - not informed or not clear in the article). At the bottom, distribution among types of Atlantic Forest (Dense Rainforest, Mixed Araucaria Rainforest, Seasonal Semideciduous Forest, Restoration sites).

but is also probably influenced by the concentration of universities and other research facilities in the same region, potentially leading to a higher level of detection and reporting than for other regions of the country. Similarly, the high level of IES reporting for Cerrado vegetation possibly reflects the loss of almost $50 \%$ of its habitat (Klink \& Machado 2005), caused mainly by its use for raising cattle, which is in turn associated with invasion by exotic grasses (Pivello et al. 1999). However, other sources of IES, such as silviculture, are also important in the Cerrado (Abreu \& Durigan 2011). The number of reports for Caatinga is also high, considering its harsh semi-arid environments, as well as the relative scarcity of research dedicated to this vegetation (Santos et al. 2011). Nonetheless, figures for the Atlantic Forest, Cerrado and Caatinga appear to be remarkable in the context of the absence of figures from reports covering Amazonia and Pantanal (together 50\% of the country surface); this is probably due to the absence of research about the issue, not to any absence of IES in those regions.

Aiming to present an overview about invasive alien plants in tropical countries, Petenon \& Pivello (2008) conducted research into high impact international journals and, as a result, found that studies about South America were scarce and Brazil was cited in only a single paper, which supports our approach of reviewing a broad spectrum of academic works. To date, roughly $50 \%$ of reports concerning IES in Brazil are not published in peer-reviewed journals and, in spite of its lower reliability, our picture of the way in which IES has been assessed in Brazil will not be accurate if it is restricted to peer-review journals.

Randall et al. (2008) surveyed patterns among the lists of IES in the United States, developing a protocol for categorizing species according to their impact, geographic distribution, species propagation and management complexity. However, due the lack of such information for most exotic species, this protocol could not be globally adopted, as expected. Considering the information gap for invasive plants in Brazil, Zenni \& Ziller (2011) have proposed a Brazilian invasive exotic species list extracted from a database created by the Instituto Hórus (Hórus Institute, a Brazilian conservation NGO focused on biological invasions). However, the database was a collaborative task, gathering information from papers and academic works, but also from reports from researchers and practitioners from around the country. This has led to the risk of self-referential information, whereby database entries are made by researchers who then cite this database as a justification for applying an "invasive" label to these species.

Indeed, for $65 \%$ of the species reviewed here the assigned invasive potential was not based on any field research (Table S2), but on a reference in the Hórus Institute database, which represents Brazil in the Invasive Information Network (I3N). While the usefulness of such collaborative databases as a repository of critical information is clear, and even the present scarcity of information may make unavoidable the use of such information to support public policy, poorly supported information will however undermine political legitimacy of policies concerning IES (Sandvik et al. 2013).

Nonetheless, there is no substitute for traditional scientific information as a basis for clear statements of invasive behavior. Although the assignment of invasive potential based on species traits can be useful in prevention strategies (Randall et al. 2008), it is only a first step and cannot substitute for the observation of invasive behavior in the actual target vegetation (Thompson \& Davis 2011).

Moreover, while the existence of informal reports from the community of researchers and practitioners may suggest that invasive behavior probably occurs, it has 
not yet been scientifically documented, highlighting the need for further studies. These observations, together with information about the site history, are a step in the process of determining invasive behavior, as a precursor to more detailed investigations using demographic sampling (Sandvik et al. 2013). Ideally, where the alleged invasive behavior of a species has been found based on qualitative field observations, it should be subject to quantitative sampling, carried out preferably on more than one site (Bourscheid \& Reis 2010). Although absolute standardization of field methods may not be feasible, establishment of minimum data requirements should not be an obstacle to building an effective public policy for invasive alien species monitoring and control.

Another important research issue is the establishment of causal relationships between biological invasion and changes in biodiversity and/or functioning of the ecosystem (Goodenough 2010). Few studies in Brazil have demonstrated this relationship using appropriate methodology with an efficient experimental design (see Pivello et al. 1999; Dislich et al. 2002; Hoffmann et al. 2004; Almeida et al. 2010; Bourscheid \& Reis 2010) and, considering the size of the list of likely invasive plants in Brazil (54 species), there poses researchers a very large challenge.

Thus, the role of scientific research and publication is crucial both to reducing uncertainty about the actual invasive status of several exotic species in Brazil and to the establishment of causal relationships between IES and ecosystem changes, which is important to support adequate management decisions. In spite of the existence of a high number of reports from some regions, such as the Atlantic Forest, research about IES in Brazil is still in its early phase. The existence of a collaborative database with national coverage is certainly positive, but researchers and conservation practitioners, who are the primary source of information for a such repository, must avoid self-reference, grounding their reports in objective field data.

As a last word, while there is a huge gap in knowledge of biological invasion in Brazil, the need for further research cannot be used as justification for inaction in terms of public policy, and the precautionary principle should be employed in temporary solutions, aiming to avoid irreversible damage.

\section{Acknowledgements}

The authors thank three anonymous referees for helpful comments and criticism on an earlier version of the manuscript. CNPq provided grants to JMDT (grants 313854/2009-2 and 503836/2010-9), JD and MCM thanks CAPES and RB the Fundação Araucária for grants.

\section{References}

Abreu RCR \& Durigan G, 2011. Changes in the plant community of a Brazilian grassland savannah after 22 years of invasion by Pinus elliottii Engelm. Plant Ecology \& Diversity, 4:269-278. http://dx.doi.org/10.1080/17550874.2011.594101
Almeida RS et al., 2010. Campo sujo úmido: fisionomia de cerrado ameaçada pela contaminação de Pinus elliottii Engelm. na estação ecológica de Itapeva, estado de São Paulo. Revista do Instituto Florestal, 22:71-91.

Biondi D \& Macedo JH, 2008. Plantas invasoras encontradas na área urbana de Curitiba (PR). Floresta, 38:129.

Blumenthal DM, 2006. Interactions between resources and enemy release in plant invasion. Ecology Letters, 9:887-895. PMid:16796578. http://dx.doi. org/10.1111/j.1461-0248.2006.00934.x

Bourscheid K \& Reis A, 2010. Dinâmica da invasão de Pinus elliottii Engelm. Em restinga sob processo de restauração ambiental no Parque Florestal do Rio Vermelho, Florianópolis, SC. Biotemas, 23:23-30.

Dislich R, Kisser, N \& Pivello VR, 2002. A invasão de um fragmento florestal em São Paulo (SP) pela palmeira australiana Archontophoenix cunninghamiana $\mathrm{H}$. Wendl. \& Drude. Revista Brasileira de Botânica, 25:55-64. http:// dx.doi.org/10.1590/S0100-84042002000100008

Droste T, Flory SL \& Clay K, 2010. Variation for phenotypic plasticity among populations of an invasive exotic grass. Plant Ecology, 207:297-306. http://dx.doi.org/10.1007/ s11258-009-9673-5

Goodenough AE, 2010. Are the ecological impacts of alien species misrepresented? A review of the "native good, alien bad" philosophy. Community Ecology, 11:13-21. http:// dx.doi.org/10.1556/ComEc.11.2010.1.3

Hoffmann WA et al., 2004. Impact of the invasive alien grass Melinis minutiflora at the savanna-forest ecotone in the Brazilian Cerrado. Diversity and Distributions, 10:99-103. http://dx.doi.org/10.1111/j.1366-9516.2004.00063.x

Klink CA \& Machado RB, 2005. Conservation of the Brazilian Cerrado. Conservation Biology, 19:707-713. http://dx.doi. org/10.1111/j.1523-1739.2005.00702.x

Lockwood L, Hoopes MF \& Marchetti MP, 2007. Invasion ecology. Oxford: Blackwell Publishing.

Mack RN et al., 2000. Biotic invasions: causes, epidemiology, global consequences, and control. Ecological Applications, 10:689-710. http://dx.doi. org/10.1890/1051-0761(2000)010[0689:BICEGC]2.0.CO;2

Martins CR et al., 2004. Levantamento das gramíneas exóticas do Parque Nacional de Brasília, Distrito Federal, Brasil. Natureza \& Conservação, 5:23-30.

Meiners SJ, Pickett STA \& Cadenasso ML, 2001. Effects of plant invasions on the species richness of abandoned agricultural lands. Ecography, 24:633-644. http://dx.doi. org/10.1034/j.1600-0587.2001.240602.x

Petenon D \& Pivello VR, 2008. Plantas invasoras: representatividade da pesquisa dos países tropicais no contexto mundial. Natureza \& Conservação, 6:65-77.

Pivello VR, Shida CN \& Meirelles ST, 1999. Alien grasses in Brazilian savannas: a threat to the biodiversity. Biodiversity and Conservation, 8:1281-1294. http://dx.doi org/10.1023/A:1008933305857

Randall JM et al., 2008. The invasive species assessment protocol: a tool for creating a regional and national list 
of non-native plants that negatively impact biodiversity. Invasive Plant Science and Management, 1:36-49. http:// dx.doi.org/10.1614/IPSM-07-020.1

Sandvik H et al., 2013. Generic ecological impact assessments of alien species in Norway: a semi-quantitative set of criteria. Biodiversity and Conservation, 22:37-62. http:// dx.doi.org/10.1007/s10531-012-0394-Z

Santos JC. et al., 2011. Caatinga: the scientific negligence experienced by a dry tropical forest. Tropical Conservation Science, 4:276-286.

Schmidt JP \& Drake JM, 2011. Why are some plant genera more invasive than others? PLOS ONE, 6:e18654. http:// dx.doi.org/10.1371/journal.pone.0018654
Seastedt T, 2009. Traits of plant invaders. Nature, 459:783-784. PMid:19516327. http://dx.doi.org/10.1038/459783a

Thompson K \& Davis MA, 2011. Why research on traits of invasive plants tells us very little. Trends in Ecology \& Evolution, 26:155-156. PMid:21334760. http://dx.doi. org/10.1016/j.tree.2011.01.007

Van Kleunen M, Webwe E \& Fischer MA, 2010. Meta-analysis of trait differences between invasive and non-invasive plant species. Ecology Letters, 13:235-245. PMid:20002494. http:// dx.doi.org/10.1111/j.1461-0248.2009.01418.x

Zenni RD \& Ziller SR, 2011. An overview of invasive plants in Brazil. Revista Brasileira de Botânica, 34:431-446. http:// dx.doi.org/10.1590/S0100-84042011000300016

Received: November 2012

First decision: December 2012 Accepted: February 2013 